\title{
Note
}

[Agr. Biol. Chem., Vol. 33, No. 6, p. 965 966, 1969]

\section{On the Fermenting Ability of Sand Cultures of Acetone-Butanol Organisms Stored for Long Years}

\author{
By Bunzo Rokusho and Masayo Yamazaki \\ Shizuoka Women's College \\ Received November 11, 1968
}

One of the authors" has previously reported on the fermenting ability of the sand cultures of acetone-butanol organisms stored for long years. The fermenting ability was tested in sand cultures of three strains (B. Y., B. G. P. and Rokusho No. 1) of Clostridium acetobutylicum, and it was found that even the sand culture stored at room temperature for 38 years had still maintained normal fermenting ability. All of these sand cultures tested had been prepared according to Weizmann's method.

In the present paper the results of fermentation test of the sand cultures stored at room temperature for $34 \sim 46$ years long are described.

A small amount of the sand culture was inoculated to $10 \mathrm{ml}$ of 3 per cent sterilized mash of unpolished rice in a test tube and incubated anaerobically at $37 \sim 38^{\circ} \mathrm{C}$. A small portion of the germinated mash was then inoculated to $10 \mathrm{ml}$ of 4 per cent sterilized mash of unpolished rice in a test tube (the rate of inoculant was abut 5 per cent) and after three transfers at $24 \mathrm{hr}$ intervals, the $10 \mathrm{ml}$ of fermented mash was transfered to $140 \mathrm{ml}$ of about 9 per cent mash of unpolished rice in a $300 \mathrm{ml}$ Erlenmyer flask. The mash in an Erlenmyer flask was prepared as follows: To $12 \mathrm{~g}$ of unpolished rice meal $140 \mathrm{ml}$ of tap water was added and the mixture was sterilized at $130^{\circ} \mathrm{G}$ for $90 \mathrm{~min}$ under pressure. The starch value of unpolished rice used was

Table I. Fermentation Data

\begin{tabular}{|c|c|c|c|c|c|c|c|}
\hline \multirow[b]{3}{*}{ Strains } & \multicolumn{2}{|c|}{ and culture tested } & \multicolumn{5}{|c|}{$\begin{array}{c}\text { Results of analyses of fermented mashes } \\
\text { Solvents produced }\end{array}$} \\
\hline & \multirow{2}{*}{$\begin{array}{c}\text { Year of } \\
\text { sand culture } \\
\text { preparation }\end{array}$} & \multirow{2}{*}{$\begin{array}{l}\text { Years } \\
\text { of } \\
\text { storage }\end{array}$} & \multirow{2}{*}{$\begin{array}{c}\text { Acetone } \\
\mathrm{mg} / 100 \mathrm{ml}\end{array}$} & \multirow{2}{*}{$\begin{array}{l}n \text {-Butanol } \\
\mathrm{mg} / 100 \mathrm{ml}\end{array}$} & \multirow{2}{*}{$\begin{array}{c}\text { Ethanol } \\
\mathrm{mg} / 100 \mathrm{ml}\end{array}$} & \multicolumn{2}{|c|}{ Total solvents } \\
\hline & & & & & & $\mathrm{mg} / 100 \mathrm{ml}$ & $\begin{array}{l}\text { \% yield based on } \\
\text { starch value }\end{array}$ \\
\hline (a) & 1934 & 34 & 700 & 1139 & 266 & 2105 & 34.7 \\
\hline B. Y. (b) & 1924 & 44 & 600 & 1246 & 229 & 2075 & 34.8 \\
\hline l(c) & 1960 & 8 & 720 & 1184 & 304 & 2208 & 35.7 \\
\hline$C p \int^{(a)}$ & & & 484 & 903 & 147 & 1534 & 24.8 \\
\hline G.P. $\left\{\begin{array}{l}\left(a^{\prime}\right) \\
\text { (n) }\end{array}\right.$ & 1930 & 38 & 634 & 1127 & 316 & 2077 & 35.3 \\
\hline $\mathrm{R} 1 *$ & 1922 & 46 & 573 & 1199 & 207 & 1979 & 33.2 \\
\hline
\end{tabular}

* Rl is the same to Rokusho No. 1 in the previous report.

1) B. Rokusho, Nippon Nogeikagaku Kaishi, 34, 942 (1960). 
71.5 pen cent.

All fermentations were ended in $48 \mathrm{hr}$ and the mashes were then analized.

Acetone was determined by Messinger's method, and $n$-butanol and ethanol were assayed by Christensen's method.

The results of the analyses of the fermented mashes are presented in the following table.

The sand cultures of B. Y. (b) and B. Y. (a) have been stored for 44 years and 34 years, respectively. The both strains vigorously fermented as the strain B. Y. (c) stored for 8 years. The strain B.G.P. (a) stored for 38 years produced smaller quantities of solvents than others, but after one treatment of "heat shock" ( $100^{\circ} \mathrm{C}$ for $\left.1 \mathrm{~min}\right)$, it recovered normal fermenting ability and produced normal quantities of solvents as shown in B. G.P. $\left(a^{\prime}\right)$ of the table. The strain Rl stored for 46 years still maintains the normal fermenting ability.

Based on the above data, it is plausible that the sand culture of acetone-butanol bacteria maintain their fermenting ability for considerablely long years, if the sand culture is properly prepared. 